\title{
O fluxo da consciência em Elói, de João Gaspar Simões
}

\author{
Valda Suely da Silva Verri*
}

A constante busca dos ficcionistas por modificações temáticas e novas formas de expressão sempre esteve ligada ao intuito de exprimir o homem (CANDido, 1972) e seus anseios. Nesse sentido, a prosa de ficção, no Modernismo, adquire diferentes formas, pois o romance tradicional, centrado na ação, parecia não mais traduzir os sentimentos do escritor moderno de forma que atendesse às expectativas do leitor. O romance, sobretudo a partir do século XX, transformou-se numa importante e complexa forma de expressão literária para os tempos modernos. De aparente forma de entretenimento, passou a uma forma mais acentuada de estudo da mente humana e suas relações sociais, refletindo filosoficamente sobre esses complexos assuntos. A literatura, lembra Antonio Candido (1972), exprime o homem e, depois, volta-se para sua formação enquanto um desfrutador dessa arte.

Efetivamente, tanto na Europa quanto no Brasil, em vez de um movimento uniforme, o que houve, no início do século, foram várias correntes caracterizadas pela quebra dos valores artísticos tradicionais e pela busca de técnicas e meios de expressão capazes de traduzir a nova realidade do século XX, marcada por significativas mudanças no ritmo de vida do homem. Surge, então, em meio a essas novas vertentes literárias, uma tendência de exploração introspectiva dos personagens, seus conflitos, dúvidas, ansiedades. Esse tipo de arte vem refletindo o homem ao mesmo tempo nas suas fundas raízes inconscientes e nos seus lúcidos frutos racionais, promovendo uma mistura de instinto e razão, em que a razão colabora com o instinto. Como consequência, a ação passa a ter importância secundária, como que para figurativizar o estado de espírito do personagem.

Ao final do século, Walter Benjamin se posiciona sobre o tema, reclamando uma crise do romance, justamente por vislumbrar um distanciamento entre o homem escritor e o homem enquanto ser social.

O romancista se separou do povo e do que ele faz. A matriz do romance é o indivíduo em sua solidão, o homem que não pode mais falar exemplarmente sobre suas preocupações, a quem ninguém pode dar conselhos, e que não sabe dar conselhos a ninguém. Escrever um romance significa

\footnotetext{
Doutora em letras e professora da Faculdade Alvorada de Tecnologia e Educação de Maringá, Maringá, PR, Brasil. E-mail: vsverri@yahoo.com.br
} 
descrever a existência humana, levando o incomensurável ao paroxismo (BENJAMin, 1994, p. 54).

Publicado em 1932, Elói ou romance numa cabeça é uma das obras do Movimento Presencista de Portugal. O texto narra os fatos decorridos em um dia da vida de Elói, em que se nota a relevância dedicada às percepções e sentimentos do personagem, em detrimento das próprias ações narradas, uma vez que o narrador filtra tais ações da forma como são percebidas pelo protagonista. Esse dia, de um mês de maio, conforme veremos, marca mudanças na vida do protagonista e, contraditoriamente, mostrar uma ausência de variedades que caracteriza o viver humano. Isso porque, para além da tarefa de contar uma história, é possível perceber ambiguidade no texto, o que ressalta sua qualidade literária.

Tudo começa quando Elói desperta e sente as coisas a seu redor de maneira diferente. Está bastante questionador. Manuela, a companheira com quem vive sem estar casado, segundo ele, "amigado", parece-lhe indefinível. O que sente por ela parece-lhe inexplicável. Uma mistura de amor e ódio. Elói sente, como de costume, que Manuela não corresponde a suas carícias. Não compreende a razão por que ela nunca se entrega completamente a ele. Ao se barbear no espelho, Elói não se reconhece. Com a metade do rosto já barbeado e a outra por fazer, percebe-se como se nele houvesse dois homens diferentes. Um com a feição exposta (o barbeado) e o outro se esconde por detrás da espuma. Este último, enigmático, inexplicável, não é passível de conhecimento, uma vez que está escondido atrás da espuma. As duas imagens, atuando como representações do homem privado e do ser social, vão acompanhá-lo durante todo o seu dia, sempre suscitando a dúvida: "Ou é verdade o barbeado ou é verdade o por barbear. Por que não serão ambos verdade?" (SIMÕES, 1982, p. 22).

No café da manhã, embora use a mesma xícara em que toma chá todos os dias, pela primeira vez observa-lhe o desenho. Está irritado, discute com Manuela. Tudo nela o perturba. Lembra-se de que sonhara que ela estava grávida. Isso faz desencadear em sua imaginação dúvidas infundadas em relação à fidelidade dela. Elói duvida que seja ele o pai da criança que ela espera. Lembra-se constantemente do fato de não ter sido ele o primeiro homem a possuí-la. Ela era viúva quando a conheceu. Sente ciúmes o tempo todo. Com efeito, toda a razão do ciúme está em perceber que ela está sempre distante, que não se entrega totalmente a ele, como se a vida afetiva e sexual não lhe importasse.

Na empresa, pela primeira vez, desafia verbalmente o chefe. Pela primeira vez, também, agride fisicamente alguém: o chefe. O dia parece estar marcado pelo instinto de desafio aos poderes que o fazem ser nem "ele" nem o "outro" (o "barbeado" ou o "por barbear"). Tudo se desencadeia, aparentemente, a partir do sonho na noite anterior em que teria visto a mulher grávida. Manuela não havia confirmado nem descartado a possibilidade da gravidez, suspeitava disso, mas não tinha certeza. Enciumado, ele suspeita de Lívio, um colega seu de trabalho. Mais tarde, 
suas dúvidas recaem sobre o patrão. E esse se torna o motivo aparente da agressão quando surpreende Manuela cumprimentando-o. Louco de ciúmes, ataca-o. Elói é levado pela polícia e passa algumas horas na prisão.

São significativos os momentos em que lá ele conversa com um companheiro de cela. Conforme expõe seus pensamentos ao desconhecido confidente, analisa-os. Elói começa a perceber que suas suspeitas em relação a Manuela não têm nenhuma razão palpável, mas não admite isso. Quer convencer a si mesmo de que tem razão. Na medida em que conversa com Inácio, o companheiro de cela, compara-se a ele, percebendo a segurança emocional de seu colega. Elói percebe que Inácio consegue manter uma serenidade que lhe possibilita alcançar objetivos, ao contrário dele, que vive constantemente em dúvida em relação a tudo.

Lívio vai buscá-lo na cadeia, comunicando que o patrão não havia morrido e que retirara a queixa. Os dois se dirigem a um restaurante. Jantam. Elói exagera no vinho. Confessa a Lívio o motivo da agressão. Não fica claro ao leitor por que, mas Lívio confirma a existência de um relacionamento entre Manuela e Caetano Ramos. Indica Olinda, uma moça que teria sido amante de Caetano Ramos e que poderia confirmar toda a história.

Os dois seguem para um lugar onde poderiam encontrar a moça. Elói passa algum tempo com Olinda, que confirma tudo. Depois, vendo o desespero dele, esta se arrepende, revelando que recebera dinheiro de Lívio para sustentar a mentira. Elói sai e, após algum tempo caminhando sem destino certo, volta, então, para sua casa, onde não encontra Manuela. Enfurecido, vai até a casa de Caetano Ramos e também não a encontra. Dirige-se à pensão, onde ela vivia antes de morar com ele. Conversam. Ela confessa ter conhecido um grande amor quando jovem e, com isso, justifica sua frieza em relação a ele. Já é manhã novamente. Ainda não sabem se conseguirão se entender, mas terminam juntos.

O texto mostra o confronto entre o mundo interior e mundo exterior do personagem a fim de justificar sua insatisfação. Para fazer a oposição entre esses dois mundos, contrapõe constantemente duas noções de tempo. O tempo cronológico traduz-se através de mensurações precisas como relógios, calendários etc. e se constitui num dos grandes responsáveis pelo comando das ações sociais. O tempo psicológico, por ser subjetivo, compõe-se de momentos imprecisos em que passado e presente se aproximam e, por vezes, se fundem. A natureza desses conceitos permite que o tempo cronológico, no texto em questão, atue como representação do mundo exterior, e o tempo psicológico, do mundo interior do protagonista. Essas duas noções de tempo permeiam toda a obra, o que contribui para mostrar os conflitos interiores, próprios do personagem - o que se faz através da voz do narrador que pode penetrar na mente de Elói e também vê-lo de fora -, revelando toda sua preocupação com questões relativas ao tempo. Nesse ponto, podemos nos valer da manifestação de Mayerhoff (1976, P. 25): 
O tempo, ou o aspecto histórico da existência humana, tornou-se o ponto focal para uma análise "existencialista" do homem. De acordo com Heidegger, o tempo é a categoria básica da existência, o tempo tal como é experimentado pelo próprio indivíduo, não como registrado pelo especialista em ciências naturais ou pelo historiador. O tempo é carregado de "significação" para o homem porque a vida humana é vivida à sombra do tempo; porque a pergunta o que "sou" apenas faz sentido em termos do em que me tenho "tornado", isto é, em termo dos fatos históricos objetivos juntamente com o modelo de associações significativas constituindo a biografia ou a identidade do eu.

Nesse romance, a temporalidade já se apresenta relevante, a começar pelo tempo de duração da história, de aproximadamente vinte e quatro horas. A narração tem início ao amanhecer e finaliza com o amanhecer do dia seguinte, constituindo uma diegese linear e organizada, medida pelo tempo cronológico. Se considerássemos como parâmetro a totalidade da vida de Elói anterior a esse dia, poderíamos afirmar que a diegese, nesse texto, é constituída de um tempo excessivamente curto, que reflete, entretanto, de maneira significativa, um tempo mais amplo das vivências interiores do personagem. Ou seja, metaforicamente, esse tempo que, em nível textual e explícito, é delimitado à extensão de um dia, pressupõe uma dimensão temporal muito mais ampla, porque, como veremos ao longo deste trabalho, projeta expressivamente o tempo psicológico do personagem, tornando ambígua a significação geral da obra. Chamamos a atenção para uma passagem da manhã de Elói, marcada pelo tempo psicológico, em que está na mesa, tomando chá e, ao observar a xícara:

Nunca ter descoberto tão exótica paisagem! E para quê? Para se sentir assim incomodado? Com efeito, uma angústia incompreensível se apodera dele. O chá embrulha-se-lhe na garganta, a ponto de se supor incapaz de evitar o vômito. Sem saber o porquê, lembra-se de só uma vez ter sido vítima de uma angústia semelhante. Há quanto tempo! E, ante si, o mesmo homem, o mesmo aborto, mostra, sobre os ombros, em vez de cabeça, um hemisfério. Então, quis afastar a vista, mas não pôde. Precisou de fazer um esforço sobre-humano para esconder-se na plataforma do elétrico. Mais um segundo, e tinha vomitado dentro do carro. Agora a impressão repetese. Aquela chávena mantém uma ligação secreta com o anúncio do carro elétrico. Lá, era o homem, o aborto; aqui, são as flores vivas e tristes, o rio cinzento, o barco abandonado (Simões, 1982, p. 29).

O personagem identifica com outro fato de sua vida a sensação experimentada ao atentar para o desenho da xícara. Assim, a duração interior do personagem é projetada no mundo das coisas, fazendo com que o presente se aproxime do passado pela sensação. É o momento "especioso", segundo explica Meyerhoff (1986, p. 17): "usado também para sugerir que o fluxo de tempo dentro do presente já contém alguns elementos primitivos de ordem e direção apontando para o 'passado' 
e para o 'futuro'. É sintomático que o texto se centre na subjetividade do protagonista. Subjetividade que é retratada nesses intervalos e em vários momentos, acompanhando o fluir de sua consciência. O tempo psicológico é relevante nesta obra, assim como o cronológico. Há trechos em que o personagem se perde em divagações. Ações que por si seriam rápidas, como diálogos, tornam o discurso longo, uma vez que o narrador se demora em retratar os pensamentos do protagonista. Aguiar e Silva manifesta-se sobre o assunto, auxiliando-nos a elucidar a questão:

A diegese comporta, todavia, outro tempo, um tempo mais fluido e mais complexo - o tempo subjetivo, o tempo vivencial das personagens, aquele tempo que Bergson designou por "durée"e Virginia Woolf por "time in the mind". Esta temporalidade, refractária à "linearidade" cronológica, heteromórfica em relação ao tempo do calendário e do relógio, é entretecida num presente que ora se afunda na memória, muitas vezes involuntária, ora se projeta no futuro, ora pára e se esvazia. Este "tempo politemporal", diferente mas não dissociado do tempo objectivo e do tempo histórico - uma determinada vivência privada e íntima do tempo exprime ou reflecte, em parte, uma determinada problemática do tempo histórico, do tempo "público" -, caracteriza particularmente a diegese do chamado "romance psicológico moderno", isto é, um romance contemporâneo e posterior às análises de Bergson sobre o fluxo ininterrupto do tempo psicológico, de William James sobre a "corrente de consciência", de Freud e outros psicanalistas sobre o inconsciente (SILVA, 2004, p. 747-748).

Nesse sentido, o presente trabalho tem por objetivo analisar essas passagens narrativas em que o romance se pauta pelo tempo psicológico do protagonista, buscando apontar a importância destas partes para o todo da obra. Para tanto, esclarecemos que esses momentos que descrevem o tempo psicológico são expressos pela técnica de escrita literária, adotada por alguns escritores do Modernismo, entendida como fluxo da consciência. Tal abordagem nos é possível com base na teoria de Robert Humphrey. Assim, faz-se necessário, a princípio, esclarecer um pouco sobre a técnica.

Esse tipo de romance, de atenções voltadas ao tempo, nos estudos até hoje existentes, tem sido constantemente identificado com o fluxo da consciência e caracterizado como psicológico, intimista ou introspectivo. É facilmente identificado pelas técnicas de expressão do fluxo da consciência, que representam os meandros e as complicações da consciência das personagens, descrevendo e analisando a formação do complexo tempo interior. Os textos de fluxo da consciência, ou corrente de consciência, englobam algumas técnicas, empregadas para expressar o aspecto introspectivo dos personagens. Como mera referência introdutória, podemos explicá-los como apresentação do que se passa na consciência de um ou mais personagens. Apresentação esta que é feita de forma supostamente exata, uma vez que aparece de forma caótica e não analisada pelo próprio personagem ou por um narrador. 
Interessa-nos, dessa forma, o sentido do termo fluxo da consciência por ser parte da nomenclatura empregada pela teoria literária para designar um tipo de expressão literária capaz de delinear com precisão o tempo psicológico. Essa literatura volta-se para indagações sobre as aspirações mais recônditas do ser humano, seus sonhos, desejos frustrações, que fluem constantemente como uma correnteza e que misturam sensações do tempo presente com a memória do passado e aspirações do futuro. O mundo expresso por esse tipo de textos existe de forma relativa, refletido ou deformado pelo espírito do personagem e não unicamente sistematizado pela visão do narrador. Frequentemente, tais obras expressam-se por meio de padrões ilógicos e não gramaticais.

Humphrey assim define o fluxo da consciência:

O romance de fluxo da consciência é identificado imediatamente por seu assunto. Este o distingue em lugar de seus propósitos ou seus temas. Consequentemente, os romances que se diz usar a técnica de fluxo-deconsciência em um grau considerável provam, em análise, ser romances que têm como assunto essencial a consciência de um ou mais personagens, isto é, a consciência descrita serve como uma tela na qual o material é apresentado nestes romances (HumpHreY, 1954, p. 2).

O monólogo interior constitui uma das técnicas utilizadas pelos romancistas contemporâneos para expressar fielmente o fluir caótico da consciência dos personagens e traduzi-la com integridade. Logo, monólogo interior é uma das técnicas de expressão do fluxo da consciência. É a que representa com mais precisão o conteúdo psíquico não pronunciado dos personagens e, talvez, por essa razão, seja associada mais facilmente a esse tipo de textos. A técnica do monólogo interior foi empregada originariamente por Édouard Dujardin (1861-1949). Segundo Aguiar e Silva:

[...] obscuro escritor francês que publicou, em 1887, um romance em que o monólogo interior era abundantemente cultivado "Les lauriers sont coupés". James Joyce reconheceu em Dujardin o inspirador da técnica dos monólogos interiores de "Ulisses", arrancando assim do olvido o romancista gaulês (SILVA, 2004, p. 748)

Para Humphrey (1954, p. 23), não há uma técnica de fluxo da consciência, mas diferentes técnicas para expressar o fluxo da consciência. São elas: monólogo interior direto, monólogo interior indireto, descrição onisciente e solilóquio. Técnicas que ele distingue e define demoradamente, na medida em que vão sendo apontadas em textos de James Joyce, Virgínia Woolf, Dorothy Richardson, William Falkner, entre outros. Como vemos, o monólogo interior constitui uma das várias técnicas para expressar o tempo interior do personagens de ficção, mas não a única. 
O termo stream of conciousness, ora traduzido como fluxo da consciência, ora como corrente de consciência, foi criado pelo psicólogo norte-americano William James em 1890 para indicar que a consciência não é fragmentada em pedaços sucessivos, não há sequência lógica ou junturas, mas, sim, um fluxo contínuo e abundante. Nesse sentido, o termo corrente, a nosso ver, não traduz um sentido condizente com o que é atribuído pelo psicólogo à expressão. Ele argumenta não apresentar o pensamento uma corrente lógica, uma sequência. Dessa forma discorre que:

A consciência, portanto, não aparece a si mesma trabalhada em pedaços. Palavras tais como cadeia ou sucessão não a descrevem adequadamente como ela se apresenta na primeira instância. A consciência não é algo juntado; ela flui. Um rio ou um fluxo são as metáforas pelas quais ela é mais naturalmente descrita. Ao falar dela, daqui por diante, chamemo-la o fluxo do pensamento, da consciência ou da vida subjetiva (JAMES, 1985, p. 132).

Concordando com este teórico, apresenta-se, a nosso ver, mais adequada a expressão fluxo da consciência, a qual adotaremos daqui por diante ao nos referirmos a esse tipo de ficção pautada pelo tempo psicológico. Afinal, conforme afirma o psicólogo, a consciência não obedece a uma sequência lógica, dessa forma não julgamos que a define da forma mais apropriada o termo corrente, que simboliza algo que se liga de forma sequencial por meio de elos.

O termo consciência, em psicologia, é empregado em sentido bastante abrangente, sendo sua definição uma tarefa complexa e de que não nos ocuparemos, uma vez que nosso objeto de estudo é o texto literário. Interessa-nos, assim, o sentido da expressão fluxo da consciência enquanto nomenclatura pertencente à teoria literária. Ou seja, a teoria literária apropriou-se, então, do termo criado pelo psicólogo para designar a expressão dos processos mentais buscada por alguns ficcionistas na modernidade. Nosso objeto de estudo é, portanto, a linguagem, articulada de maneira literária, para expressar a consciência e não a consciência por si.

Uma obra bastante característica de fluxo da consciência, segundo Robert Humphrey, é Mrs Dalloway, de Virginia Woolf (1915). Recortamos aqui um trecho inicial da obra, que narra uma cena da protagonista Clarissa diante de uma janela.

Que fresco, que calmo, mais que o de hoje, não era então o ar da manhãzinha; como o tapa de uma onda; como o beijo de uma onda; frio, fino, e ainda (para a menina de dezoito anos que ela era em Bourton) solene, sentindo, como sentia, parada ali ante a janela aberta, que alguma coisa de terrível ia acontecer; olhando para as flores, para os troncos, de onde se desprendia a névoa, para as gralhas, que se alçavam e abatiam,; parada e olhando até que Peter Walsh lhe dizia: "Meditando entre os legumes?" - Seria isso? Ou: "Prefiro as pessoas às couves-flores"? Com certeza o dissera certa manhã em que ela havia saído para o terraço - esse Peter Walsh. Regressaria da Índia por um dia desses, em junho ou julho, não 
se lembrava bem, pois as suas cartas eram incrivelmente aborrecidas; os seus ditos é que ficavam na memória; os seus olhos, o seu canivete, o seu sorriso, a sua rabugice e, quando milhões de coisas se haviam desvanecido de todo - que estranho era! - , umas poucas frases como aquelas sobre couves. Deteve-se um instante na calçada, esperando que passasse um caminhão em Durtnall (Woolf, 1972, p. 11-12).

Na descrição dos pensamentos da personagem, presente e passado se confundem. Clarissa olha a paisagem e, em seguida, lembra-se de Peter Walsh. Entretanto, o narrador não adverte o leitor de que ela se lembrou de um fato passado, apenas reproduz os pensamentos dela, da maneira como fluem. Dessa forma, ocorre um desligamento do mundo exterior. A personagem, a princípio na janela, encontrase, de repente, na rua (último parágrafo da citação) sem que o narrador dê ciência de tal mudança ao leitor. Ou seja, o narrador não se desliga do mundo interior da personagem para "auxiliar" o leitor. Esse recurso procede, estendendo-se por uma longa sequência de páginas dessa obra de Woolf. Em Elói, esse tipo de mudanças exteriores não acontece dessa forma despercebida. São marcadas as ações referentes ao mundo exterior, tornando relativamente curtos os trechos de fluxo da consciência. Vejamos o trecho abaixo que mostra também Elói refletindo diante de uma janela:

Elói dirige-se à janela na esperança de ver sair a amante. Lembra-se de que a escada é longa. Pensa: "Talvez num minuto... Às vezes uma liga caída; não tarda. Podia ter-lhe sido franco. Para que hei de prolongar este mal entendido?..." Começa a chover. "Teria ela trazido guarda-chuva?", pensa. "Que tempo! E se rasgasse o vestido nos caixotes?" (Lembra-se do vestido dela.) "Comprei-lho no dia dos anos. - Vais ver: há um, lindo, no Marques. Azul. Isso mesmo - . Como ela sorria!...” E nada. Elói conta: "Um, dois, três; - é agora!" Lembra-se de que talvez espere uma aberta. Lívio pergunta: "Onde foi o patrão, colega?" Elói encolhe os ombros, e pensa: “Sei lá! Que pergunta! Então estás aqui e não sabes?” Estremece. E, sem quê nem para quê, atravessa o escritório, arrebata a porta, lançase na escada (Simões, 1982, p. 48).

Esse trecho representa um momento crucial do personagem. Alguns minutos após o relógio ter anunciado o meio-dia, Manuela teria acabado de sair do escritório onde Elói trabalha. Ele quer sair correndo atrás dela para tentar desfazer o mal entendido da manhã. É quando impetuosamente resolve ir até ela, encontraa cumprimentando o Sr. Caetano e, perdendo o controle, agride-o.

O trecho citado permite um retrato fiel do tempo psicológico de Elói. Para resolver o que o incomoda no momento presente (seu desentendimento com Manuela), indistintamente, sua mente traz à tona o futuro, ou seja, a intenção de correr até ela e tentar reaver o acontecido. Para tanto, busca um pretexto para fazêlo através de suposições como a falta do guarda-chuva ou até mesmo o absurdo 
de ter rasgado o vestido em algum caixote. A suposição lhe traz imediatamente o passado, o dia em que ele lhe comprou aquele vestido. É a mistura entre fatos cronologicamente distantes, mas indistintos na mente que desconhece tal distância. Notamos, entretanto, que, logo em seguida, o texto passa a retratar o mundo exterior, na medida em que Elói é interrompido pela fala de Lívio e sai correndo atrás de Manuela. Diferentemente, em Mrs. Dalloway, a organização do texto se detém nos pensamentos da personagem, reproduzindo-os, demoradamente. Entretanto, ambos os trechos citados expressam o tempo psicológico através da técnica de fluxo da consciência, mostrando, nos dois casos, a expressão do tempo psicológico caracterizado pela fusão entre presente, passado e futuro.

Sobre essa passagem de Elói, ocorrida ao meio-dia, faz-se necessário pontuar que, ao agredir o patrão, Elói revolta-se contra uma autoridade social. A agressão ao Sr. Caetano Ramos representa, para Elói, uma violação da suposta figura de si mesmo, construída ao longo do tempo para a sociedade. Ou seja, Elói sempre representou o papel do filho do Sr Elói dos Santos, comerciante honrado e respeitado. Dessa forma, sente-se despir do "colete de gesso que compassivamente deixara que lhe vestissem" (SimõEs, 1982, p. 50). Além de não ter conseguido ser o comerciante que seu pai sonhara, trabalhava para Caetano que fora empregado "obediente e serviçal!" (SıмÕEs, 1982, p. 39) de seu pai. Em suma, o personagem Elói, idealizado em período de florescimento das teorias da psicanálise de Freud, estava prestes a ser pai de um bebê da Manuela. Daí a necessidade de reconstrução da imagem simbólica que guardava do pai, tanto o pai biológico, quanto o pai social.

Entre as técnicas relacionadas por Humphrey destacamos uma, habilmente empregada nessa obra, para expressar o fluxo da consciência de Elói: o monólogo interior indireto. Isso ocorre não obstante os objetivos do grupo presencista, a que pertenceu Gaspar Simões, para os quais a arte não dependia de formas estilísticas mas, sim, da essência do autor. O grupo, conforme explica Mourão-Ferreira (1977), buscava individualidade criativa, a fim de construir o que chamavam de "literatura viva”. E assim o faz Simões ao construir a figura de Elói que expressa, pela voz de um narrador, os seus mais íntimos conflitos.

Humphrey assim define o monólogo interior indireto:

Monólogo interior indireto é, então, aquele tipo de monólogo interior no qual um autor onisciente apresenta o material não dito como se fosse extraído diretamente da consciência de um personagem e, com comentário e descrição, guia o leitor. [...] O autor é um guia da cena para o leitor. Retém a qualidade fundamental do monólogo interior, no qual o que apresenta da consciência é direto; isto é, está na linguagem do personagem e com peculiaridades dos processos psíquicos dele (HuMPHREY, 1958, p. 29).

O trecho a seguir evidencia o emprego dessa técnica, quando Elói, logo após ter agredido o patrão, está sendo levado pela polícia. 
Ao menos uma vez na vida Elói tinha sido Elói. Na verdade, que arrebatadora a satisfação de nos "sentirmos nós mesmos"! E, sem saber como, sente-se percorrido por um olhar de admiração (SIMÕES, 1982, p. 51).

Peculiaridades da consciência de Elói, na fala do narrador, buscam transmitir emoções do personagem. Afinal, quem sente a tal satisfação "arrebatadora"? Elói ou o narrador? Ocorre aqui uma mistura em que as duas vozes se confundem.

O autor de Elói aproveita-se bastante dessa forma de expressão moderna para a narração da tarde. Esse é o período do dia de Elói que compreende os trechos mais extensos em que se retrata seu fluxo de consciência. Por ter acabado de cometer um ato que considera imprevisto diante dos olhos dos outros, ou seja, "o mais submisso dos empregados de escritório" (SIMõEs, 1982, p. 51) espancou o seu patrão. Daí que Elói considera "Para o futuro, a sociedade ver-se-ia obrigada a criar-lhe uma nova imagem" (SIMÕEs, 1982, p. 50). Algumas páginas do capítulo quatro descrevem fielmente seus pensamentos, mostrando sua reação diante dessa ruptura que acaba de se concretizar.

No início do capítulo, enquanto é levado pela polícia, Elói relembra suas aulas de música quando criança, a imagem do professor de música, a figura de seu pai, ao mesmo tempo que observa as pessoas que param na rua para vê-lo. Esse trecho inicial do capítulo traz à tona fatos de outras épocas, que agora vêm, indistintamente, à sua mente, que desconhece medidas temporais externas. Essa divagação é interrompida pela frase: "Chegavam à esquadra" (SIMõEs, 1982, p. 52). Assim que Elói entra na sua cela, o narrador passa a novamente retratar seus pensamentos, agora de uma forma ainda mais caótica e desorganizada, em que podemos facilmente identificar como o nível da "pré-linguagem". Para relembrar: "os níveis da pré-linguagem da consciência não são censurados, racionalmente controlados, ou logicamente ordenados" (HumpHrey, 1958, p. 3).

Elói observa o desenho da madeira no tampo da mesa ao mesmo tempo que a confunde com um rio e que vem à sua mente uma música que cantava quando criança, o livro de contas-correntes da loja em que trabalha e a imagem de Lívio. Tudo é expressão do tempo psicológico do personagem, através do fluir da consciência. Nesse trecho, presente e passado confundem-se e afloram, alheios a medidas de tempo lineares da física, ou seja, ao tempo cronológico. Revela-se, então, o instante do personagem constituído por "momentos imprecisos, que se aproximam e tendem a fundir-se, o passado indistinto do presente, abrangendo, ao sabor de sentimentos e lembranças, intervalos heterogêneos e incomparáveis" (NunEs, 200o, p. 19). A forma de escrita aqui empregada se presta, então, adequadamente, à expressão desse momento do personagem, que se encontra confuso por realizar um ato que não condiz com o que supõe que a sociedade espera dele.

Em meio a esse fluir de consciência, repentinamente, Elói percebe a presença de Inácio, o companheiro de cela: 
[...] ao fundo do tampo da mesa Elói descobre um homem deitado num colchão, que o observa com um misto de curiosidade e desdém. Não tinha dado pela sua presença. Num primeiro impulso, desvia a vista. Não lhe apetece travar relações com quem quer que seja. Contudo, momentos depois, surpreende-se a analisá-lo (SıMÕES, 1982, p. 53).

Mesmo tendo se dado conta da presença do outro, resolve não dar importância a ele e continua ensimesmado. Temos, então, a partir daí, outro trecho centrado em sua interioridade, quando "Mergulha outra vez a cabeça na mesa" (SimõEs, 1982, p. 54). Parece passar por um leve adormecimento. Vê figuras indistintas: ele próprio cantando; Manuela "que tem a boca cosida, tal como a do homem deitado no colchão” (SıMõES, 1982, p. 55); a prima Isabel; o cadáver do Sr. Caetano que não lhe causa espanto porque para ele agora "o patrão já morreu há muitos anos" (SIMÕEs, 1982, p. 55). Ressaltamos mais uma vez a peculiaridade do tempo psicológico nas figuras de diferentes épocas, quando Elói se sente interrompido por deparar-se, novamente, com a presença do desconhecido "sentado no colchão, limpando as unhas com o pau de um fósforo” (SimõEs, 1982, p. 55).

Sobre essas ações trazidas à tona indiscriminadamente, lembramos Meyerhoff, para quem:

Uma porção importante do conteúdo de nossa memória não exibe essa espécie de ordem uniforme, social, e sim, sobretudo, uma qualidade pela qual os eventos passados, presentes e futuros são dinamicamente fundidos e associados uns aos outros (MEYERHOFF, 1976, p. 20).

É esse o aspecto da mente humana construído em linguagem literária através das técnicas de fluxo da consciência que caracteriza o que Humphrey denomina nível da pré-linguagem e que, portanto, pode ser identificado com a técnica de escrita criada com a modernidade, o fluxo da consciência. Não há em Elói trechos tão longos como em Mrs. Dalloway, ou em qualquer outro texto caracterizado como de fluxo da consciência. Por essa razão, podemos dizer que não se trata de um romance de tempo psicológico ou romance de fluxo da consciência, mas um romance que apresenta alguns reflexos dessa forma de expressão literária para expressar a consciência do personagem, e que esses reflexos são encartados em momentos significativos da obra, a fim de expressar seu tempo interior, mostrando, através desse personagem, a incompatibilidade existente entre a subjetividade humana e o mundo exterior, regido este último por medidas precisas.

Ainda no capítulo quatro, esse fluxo dos seus pensamentos é interrompido pela fala de Inácio, a quem o narrador se refere ainda como um desconhecido. Inácio só passa a ser citado pelo seu nome depois que se apresenta formalmente a Elói, pois o narrador acompanha a trajetória das descobertas do protagonista. Elói e Inácio estabelecem, nesse momento da narração, um diálogo em tom de confissão. A pontuação carregada de reticências revela a subjetividade dos personagens, 
a despreocupação com o tempo cronológico e a ausência das urgências impostas pelo mundo exterior. A "paz podre da cadeia" (SImõEs, 1982, p. 58) torna-se o ambiente apropriado para se conhecerem.

Após uma confissão de Elói, o silêncio reina novamente, então, há outra centralização no seu mundo interior, quando passa a contrastar o espaço de dentro da prisão com o de fora. De dentro da prisão, tenta formar uma imagem do que acontece na rua. Ao mesmo tempo, Elói relembra a visão que já teria tido sobre aquele mesmo lugar, como o imaginava quando se encontrava fora dele. É possível perceber aí que o texto reflete sobre o tempo vivido mostrando contraste entre o que Elói pensava a respeito da prisão em outra época e como ele a vê agora. Para isso, o narrador desvenda, mais uma vez, seus pensamentos mais íntimos, confrontando presente e passado.

Elói tenta orientar-se. Que rua será aquela? Recorda-se de ter entrado na esquadra pelo lado da rua do correio. As celas ficam à direita. Só pode ser a calçada da lomba. Quando era pequeno palmilhava-a todos os dias para a escola. Lembra-se de olhar para as grades da cela, com a impressão de que lá dentro devia ser uma espécie de armazém muito escuro, muito sujo, com os homens pelo chão, de mistura com as mulheres, esfarrapados, a olharem para o tecto numa sonolência agradável. Quando o professor lhe batia, ou humilhava, vinham-lhe desejos de estar ali deitado com os homens e as mulheres, longe de todos e de tudo (SIMõES, 1982, p. 61).

A obra literária em questão, nesse momento da narração, confronta o mundo interior e o mundo exterior do personagem inclusive com o espaço interior e o exterior. A cadeia é o espaço interno e a sociedade, o externo. Da mesma forma, confronta as visões de presente e passado sobre um mesmo espaço, sob a influência do tempo vivido.

Vemos, assim, que o período da tarde não é determinado no texto pelo tempo do relógio, uma vez que o personagem se encontra afastado da vida em sociedade e do tempo cronológico. Dessa forma, predomina, nesse trecho da narração, a abordagem do seu tempo psicológico, evidenciando um momento de introspecção, conflitos, anseios, angústias do protagonista.

Quando Lívio vai buscar Elói na cadeia, a dúvida mais provável do leitor será em relação ao tempo decorrido desde que Elói foi levado para o cárcere. Não é possível saber se se passaram algumas horas ou dias. Essa informação é esclarecida apenas quando ele e Lívio mencionam o jantar (SiMõEs, 1982, p. 77). Supõe-se a partir daí que seja noite, embora não seja possível até então saber se é o início da noite ou já madrugada. Elói, ao se despedir de Inácio, o faz com um beijo na boca. Isso lhe desencadeia lembranças da infância. Nesse momento, o narrador lhe retrata o fluir dos pensamentos. 
Na escola os rapazes chamavam-lhe "pêssego" - e perseguiam-no. Houvera mesmo um que o dominara. Lembra-se de estar deitado com ele, de barriga para o ar, os olhos fechados por causa do sol, e as mãos nas mãos. As pálpebras pareciam de fogo e a mão do sedutor apertava-lhe os dedos, torneava-lhe os pulsos. Depois - mais nada. Qualquer coisa lhe repugnava naquelas carícias. Um dia quis beijá-lo. Elói recusou. Fugiu. Por vingança, passou a bater-lhe. Era um suplício. De novo entrevê os seus olhos esverdeados no espelho. Surpreende-se a soletrar as letras que o atravessam de lado a lado: "Hoje há lampreia". Pensa: "Lampreia? Que nojo!" Recorda-se do pai: "Coma! Qual não quer? A mesa é para comer, não é para chorar." A mãe intercedia: "Só o arroz, filho. Tomaram muitos comer lampreia..." Vira aquela coisa escura e gordurosa a remexer, no alguidar da cozinha. E não podia! Parecia uma cobra: uma cobra com buracos na barriga, como as flautas. "Seduzir-me?", pensa. "Queria-me seduzir?” E outra vez o atravessa uma onda de repugnância. Uma coisa é amar um homem, outra experimentar o seu contato, ser escravo do seu desejo (Simões, 1982, p. 81-82).

A primeira metade desta citação constrói, a princípio, a narração de forma mais organizada, em seguida, passa a revelar os pensamentos mais confusos do personagem, expressando seu tempo psicológico, seu fluxo de consciência. Nesse segundo momento, podemos perceber ainda a associação livre de ideias, também característica dos textos que empregam as técnicas de fluxo da consciência. A associação livre consiste em relacionar uma ideia a outra, pois a consciência, em atividade constante, não consegue permanecer por um longo espaço de tempo no mesmo foco. Dessa forma, o texto expõe os pensamentos do personagem, estabelecendo a relação entre a sensação de asco que Elói sente ao se lembrar do beijo em Inácio. O mesmo sentimento o levou a se lembrar dele criança, perseguido pelo outro garoto. A mesma sensação experimentava ainda, quando, forçado pelos pais, tinha que comer um peixe, o qual havia visto vivo sendo preparado pela mãe na cozinha. Dessa forma, vemos como o texto organiza e aproxima ações cronologicamente distantes na mente de Elói. Ratificamos com Nunes (2000) quando afirma que o tempo psicológico "é a mais imediata e mais óbvia expressão temporal humana" (SimõES, 1982, p. 19), uma vez que "a percepção do presente se faz ora em função do passado ora em função de projetos futuros” (SimõES, 1982, p. 18-19).

O período da noite do herói se prende à narração do jantar e da mentira de Lívio. O final do capítulo cinco retrata seus recônditos, buscando mostrar o que ocorre ao ver confirmada por Lívio a traição de Manuela. Uma confusão mental reforçada também pelo efeito do vinho do jantar, conforme é exemplo o trecho que destacamos a seguir.

E, insensivelmente, vê-se a si mesmo debruçado na madressilva do quintalinho da Engrácia, dizendo adeus a Manuela. Ei-la, lá vai. Dobrou agora mesmo a álea dos gerânios. A sua mão ágil, de fortes mas doces articulações, agita-se um instante por entre as folhas da latada. Os gerânios 
sobem-lhe pela saia azul, discreta, como se quisessem esconder-se-lhes no colo. Parecem bocas exangues, sôfregas de beijos. Lembra-se de ter desejado ser essas flores. Mas a mão deixou de se agitar. Aproximou-se dos lábios de Manuela e recebeu o beijo que, num segundo, atravessava latadas, madressilvas, rosas de toucar, para "ser teu, só teu, para toda a vida" (Simões, 1982, p. 93).

Para finalizar esse capítulo do romance, o texto retoma os pensamentos de Elói com as mesmas palavras com que o personagem se autoanalisava no início da narração:

O recanto desconhecido de sua alma, onde o silêncio e o pó reinavam, abriu-se-lhe, por fim. Mas o pó espalhou-se em torno; toda a sua alma mergulha agora no silêncio e no pó (SiMõES, 1982, p. 94).

A essa altura da narração são retomados os objetivos traçados pelo personagem no início da obra. Elói já reconhece ter conseguido remexer naquilo que o tempo havia deixado abandonado em algum lugar de sua mente, mas que ainda não resolveu, apenas revolveu. Conforme veremos adiante, o final da narração mostra que o passado não se reconstitui, mas se reencaminha.

A madrugada é narrada no capítulo seis, e tem como centro de interesse a conversa de Elói com Olinda. Essa parte da obra consta ainda de momentos bastante introspectivos em que o autor se vale das técnicas de fluxo da consciência para revelar momentos de considerável importância para o percurso narrativo. Nesse momento, o protagonista é apresentado sob efeito do vinho, justificando, em parte, a forma rudimentar de apresentar seus pensamentos.

Pela expressão do tempo psicológico, é trazida à baila a preocupação do personagem com a imagem do relógio, afirmando essa presença constante em sua mente. Destacamos um trecho de fluxo da consciência de considerável importância, que descreve a confusão do personagem, quando vê confirmada por Olinda a traição de Manuela. Ao receber tal confirmação, sua reação é mergulhar a cabeça numa almofada. Então são descritos muitos fatos de seu passado que emergem repentinamente. Ao sentir o cheiro de brilhantina na fronha do travesseiro, desencadeiamse lembranças do cabeleireiro que frequentava quando criança. A lembrança do cabeleireiro é imediatamente seguida da imagem do relógio cuco, que, interpretada pela visão de Elói, agora adulto, estaria incumbido de distrair as crianças enquanto cortavam o cabelo. Vê-se, nesse sentido, que a preocupação constante do personagem com o relógio acompanha-o desde a infância:

E Elói põe-se a ouvir o "cuco" do cabeleireiro que lhe cortava as loiras madeixas de bebé. Da casota negra saía um passarolo negro e, enquanto a tesoura lhe mastigava os cabelos, o passarolo cantarolava: "cu-cu; cu-cu". Extraordinário cabeleireiro! Qual Colombo, soubera descobrir o "ovo” de 
um cuco para seduzir os meninos a quem seus grandes bigodes assustavam! (Simões, 1982, p. 105).

A narração de imagens do passado aflorando no presente presta-se a evidenciar o estado mental conflitante do personagem, pois tais imagens situam-se num momento da narração em que o texto busca enfocar a reação do personagem diante de uma descoberta angustiante. Olinda acabara de declarar a Elói que existia um caso amoroso entre Manuela e Caetano Ramos e que toda a sociedade tinha conhecimento disso. Outro momento importante da narração se dá algumas páginas adiante, quando Olinda desmente o que havia dito. O texto mostra novamente a confusão nos pensamentos de Elói, que perde, por alguns momentos, a nitidez das ideias:

E como a sombra lhe confunde a imagem, afigura-se-lhe ver duas covas no lugar dos olhos. Um dia será cadáver! Ele, Elói, aquele corpo desajeitado que cresceu, cresceu desde o berço, e uma mão maternal acompanhou nos primeiros passos - um dia deixará de existir. Mais sozinho do que nunca, desaparecerá na terra escura... Ele, Elói, deixará de existir! (SIMÕES, 1982, p. 112).

A expressão do fluxo da consciência enfoca, agora, um momento de descobertas do personagem e a confusão de sua mente. Da mesma forma, retrata Elói ainda sob efeito da bebida do jantar. A organização literária da obra destaca, então, os momentos mais introspectivos do personagem. O mesmo recurso é empregado também quando Elói está sendo levado para a cadeia. É a ocasião da descoberta, do rompimento com a autoimagem construída até então.

O capítulo sete narra outra parte da madrugada em que Elói já se encontra sozinho na rua. Aí, a descrição tem relevância considerável no sentido de apontar a passagem do tempo no interior do personagem e confrontá-la à do tempo exterior. É nesse momento que Elói retoma o tempo do relógio, esquecido desde o meio-dia, quando teria cometido o ato que mudou sua rotina. Até então, estivera tão envolvido pela agressão que cometera e, sobretudo, por tentar descobrir se tinha razão para tê-la cometido, que estivera completamente desligado do tempo exterior. $\mathrm{O}$ trecho que se segue reproduz o momento em que ele recomeça a perceber a realidade: "Dia infindável! Há quanto tempo dura aquela luta como os fantasmas? Enganado? Não enganado?” (SIMÕES, 1982, p. 116).

O texto apresenta explicitamente a mais evidente característica do tempo psicológico: a descoincidência da duração interior do personagem com as medidas de duração externa. É quando Elói começa a retomar a consciência do tempo exterior decorrido. O leitor não é informado de quanto tempo Elói passou na cadeia, até que ele saia e mencione a hora do jantar, que também não se sabe exatamente a que horas se deu. Do capítulo quatro ao capítulo sete, ou seja, desde o meio dia 
até às duas horas da madrugada, o personagem estivera despercebidamente envolvido em seu mundo interior. Essa passagem aborda a imprecisão do tempo interior do personagem, mostrando ser um tempo subjetivo, que não pode ser medido em horas, minutos ou dias. Ou conforme explica Mendilow (1972, p. 131):

[...] um tempo relativo, interior, estimado através de valores que variam constantemente, em contraste com o tempo exterior, medido através de padrões fixos. Necessariamente uma hora não precisa representar um montante de atividade consciente igual ao de uma outra.

Como o personagem começa, aí, a querer retomar a consciência do tempo exterior, é nesse momento também que retoma o jornal, comprado pela manhã, que agora volta a "apalpar na algibeira esquerda" (SıмõEs, 1982, p. 117). O jornal atua, então, como símbolo do tempo cronológico, dada sua ligação ao cotidiano e à objetividade. A retomada do jornal comprado pela manhã indica que o ciclo de seu dia começa a se fechar. Constitui-se, assim, o clímax da narrativa. Elói está voltando à realidade, ao mesmo tempo que retoma a consciência do tempo cronológico, após ter destruído a imagem de filho do "honrado comerciante" (SIMÕEs, 1982, p. 22) Elói Maria dos Santos. Dessa forma, a organização narrativa, suspendendo a informação das horas e fazendo com que o personagem retorne a elas, espelha o tempo psicológico, ressaltando a descoincidência entre este e as medidas exteriores. É nesse ponto da narração que ele se volta novamente ao relógio:

Mal vê os ponteiros à tênue luz do bico de gás. Precisa de fazer um esforço para descobrir que o das horas está imóvel sobre as duas e o dos minutos se abeira do meio-dia. "Duas horas!", exclama. E como se pudesse não ter compreendido, repete, em voz alta: "Duas horas!” (SIMÕES, 1982, p. 116, grifo nosso).

A perfeita sintonia da construção textual ajusta seu conteúdo à forma. Lembramos novamente que os trechos de fluxo da consciência mais significativos são, conforme vimos, empregados no período do meio-dia às duas da manhã, entre os capítulos quatro e sete. $\mathrm{E}$, mais especificamente, que os trechos narrados a partir do fluxo da consciência de Elói estão em momentos de significativas descobertas do personagem. São eles: o momento em que está sendo levado para cadeia por ter rompido com sua antiga imagem social; o momento em que Olinda Confirma a traição de Manuela e o momento em que ela nega a traição.

O tempo da diegese, como já mencionamos, é preciso. A história tem início pela manhã e termina na manhã do dia seguinte. Corresponde, portanto, a um dia do personagem em que o ciclo se inicia com o clarear do dia e se fecha com o clarear do dia seguinte. Um dia que não é descrito pelo seu ciclo normal, do nascer ao pôr do sol, mas, sim, do nascer ao outro nascer, enfocando a ideia de recomeço. Dizer que a narrativa termina ou que o ciclo se fecha tem sentido relativo. Ao final, 
Elói e Manuela têm uma conversa que parece modificar sua relação, mas não há uma definição para a situação. Assim, as dúvidas de Elói não se esgotam, o conflito interior não termina, apenas se modifica após passar por obstáculos. Entendemos, então, implícita no texto, a visão da renovação da vida e, ao mesmo tempo, da repetição cotidiana. Repete-se porque o dia seguinte amanhece, dado objetivo, referente ao tempo físico. Entretanto, o novo dia traz novos conflitos. Novos anseios surgem, efetivando a fugacidade das ansiedades humanas. O desfecho da obra comprova essa reflexão:

Manuela lembra-se: Elói escrevia sempre nos sobrescritos: Para o Exmo Senhor", durante anos e anos; um dia deixou, repentinamente de escrever "Para". E disse: este sobrescrito não chega ao seu destino. E não chegou: quando o distribuidor entregava a carta no seu destino, o destinatário acabava de morrer (SIMÕES, 1982, p. 143).

A personagem reflete sobre devir. O tempo, que se faz notar de forma quantitativa, atua sobre o indivíduo de forma qualitativa e flui irreversivelmente, modificando o homem de forma irrecuperável. Pois, assim como é irreversível o tempo cronológico, também o é o psicológico. Daí a razão da afirmação "o destinatário acabava de morrer". A reflexão de Manuela questiona a irreversibilidade do tempo, tanto cronológico, quanto psicológico.

Efetivamente, a obra vai além do objetivo de contar uma história para deleitar o leitor. Perpassa, em muitos momentos, ações que beiram a melancolia. Afinal, queremos ressaltar que, em literatura, para além do prazer de ler a história narrada, há que se considerar o prazer de ler o modo como ela está estruturada e que a faz "arte", não importando quão pessimista possa parecer a visão do mundo carreada por ela.

\section{Referências}

Benjamin, Walter. A crise do romance. In: Benjamin, Walter. Magia e técnica, arte e política: ensaios sobre literatura e história da cultura. 7. ed. Tradução de Sérgio P. Rouanet. São Paulo: Brasiliense, 1994. p. 54-6o.

CANDido, Antonio. A literatura e a formação do homem. Ciência e cultura, n. 24, p. 803-809, 1972.

Humphrey, Robert. Stream of consciousness in the modern novel. Oakland: University of California Press, 1954 .

James, William. Princípios de psicologia. Tradução de Pablo Rubén Mariconda. In: James, William. Pragmatismo e outros textos. 2. ed. São Paulo: Abril Cultural, 1985. p. 118-169. (Coleção Os pensadores). 
Mendilow, Adam Abraham. O tempo e o romance. Tradução de Flávio Wolf. Porto Alegre: Globo, 1972.

Meyerhoff, Hans. O tempo na literatura. Tradução de Myriam Campello. São Paulo: Mc Graw-Hill, 1976.

Mourão-Ferreira, David. Presença da "Presença". Porto: Brasília, 1977.

Nunes, Benedito. O tempo na narrativa. São Paulo: Ática, 2000.

Silva, Vítor Manuel de Aguiar e. Teoria da literatura. 8. ed. Coimbra: Almedina, 2004 .

SimõEs, João Gaspar. Elói ou romance numa cabeça. Mem Martins: EuropaAmérica, 1982.

Woolf Virginia. Mrs. Dalloway. Tradução de Mário Quintana. São Paulo: Abril Cultural, 1972.

Recebido em 19 de fevereiro de 2017.

Aprovado em 22 de junho de 2017.

\section{Resumo/Abstract/Resumen}

\section{O fluxo da consciência em Elói, de João Gaspar Simões}

Valda Suely da Silva Verri

Este trabalho tem como principal objetivo fazer uma leitura da obra Elói ou romance numa cabeça de João Gaspar Simões, por meio da qual se observa a influência da técnica de escrita literária modernista denominada fluxo da consciência. Auxiliados pelos estudos feitos por Robert Humphrey, podemos identificar essa técnica empregada em alguns trechos da obra e, ao final, justificar seu emprego nas passagens narrativas em que se encontram, uma vez que se prestam a expressar o tempo psicológico do protagonista.

Palavras-chave: Elói, fluxo da consciência, tempo psicológico, Modernismo.

\section{The flow of consciousness in Elói, by João Gaspar Simões}

Valda Suely da Silva Verri

The primary objective of this work was to make a reading of Elói ou romance numa cabeça by João Gaspar Simões whereby the influence of the modernist narrative device known as 'stream of consciousness'. With the assistance of Robert Humphrey's studies, this technique was found in certain sections of the novel and its use 
can be justified in those narrative passages where it appears as it is employed to express psychological time as experienced by the protagonist.

Keywords: Elói, stream of consciousness, psychological time, Modernism.

\section{El flujo de la conciencia en Elói, de João Gaspar Simões}

Valda Suely da Silva Verri

Este trabajo tiene como principal objetivo hacer una lectura de la obra Elói ou romance numa cabeça de João Gaspar Simões, por medio de la cual se observa la influencia de la técnica de escritura literaria modernista denominada flujo de conciencia. Auxiliados por los estudios de Robert Humphrey podemos identificar el empleo de esta técnica en algunos fragmentos de la obra y justificar su empleo en los pasajes narrativos en que se encuentran, toda vez que se sirven para expresar el tiempo psicológico del protagonista.

Palabras clave: Elói, flujo de conciencia, tiempo psicológico, Modernismo. 